\title{
Spatial distribution of soil chemical properties in an organic farm in Croatia
}

Igor Bogunovic ${ }^{1 *}$; Paulo Pereira²; Eric C. Brevik ${ }^{3}$

1University of Zagreb, Faculty of Agriculture, Department of General Agronomy, Zagreb, Croatia (ibogunovic@agr.hr)

2Environmental Management Center, Mykolas Romeris University, Ateities g. 20, LT-08303

Vilnius, Lithuania (pereiraub@gmail.com)

${ }^{3}$ Department of Natural Sciences, Dickinson State University, Dickinson, ND, USA

(eric.brevik@dickinsonstate.edu)

*corresponding author: Igor Bogunovic (ibogunovic@agr.hr) 


\section{Abstract}

Soil pH, electrical conductivity (EC), organic matter (OM), available phosphorus (AP), and potassium (AK) are some of the most important indicators of soil fertility. These soil parameters are highly variable in space and time, especially in agricultural areas, with implications for crop production. The aim of this work was to study the spatial variability of $\mathrm{pH}, \mathrm{EC}, \mathrm{OM}, \mathrm{AP}$ and $\mathrm{AK}$ using kriging and co-kriging methods in the Rasa River Valley (Croatia). As co-variates for each variable we considered the distance from the sea (DFS), distance from the river channels (DFC), pH, EC, OM, AP and AK. Only the variables with a significant correlation with the predictor were used as predictor variables. The results showed that soils of the study area had high $\mathrm{pH}, \mathrm{EC}, \mathrm{OM}$ and AK values and a low concentration of AP. The spatial variability was high for EC and low for pH levels. pH, EC, OM and AK had significant positive correlations. All these variables had significant negative correlations with AP. The exponential model was the best to model OM, AK and AP. Spherical and Gaussian models were the most accurate to model $\mathrm{pH}$ and EC. Spatial dependence was high for soil $\mathrm{AK}, \mathrm{EC}$ and $\mathrm{pH}$, and moderate for soil $\mathrm{OM}$ and $\mathrm{AP}$. The incorporation of auxiliary variables increased the precision of the estimations. CoK_DFS was the best method to predict soil EC and AP, while Cok_EC, was better to estimate soil pH and Cok_pH and Cok_OM predicted soil OM and AK with the best accuracy. The maps produced with the best predictors showed that $\mathrm{pH}, \mathrm{EC}, \mathrm{OM}$ and $\mathrm{AK}$ had high levels in the northern and eastern parts of the study area. The opposite trend was identified in relation to the AP spatial pattern.

Keywords: Auxiliary data; Co-kriging; Nutrient maps; Geostatistics 


\section{Introduction}

The current use of unsustainable agricultural practices is contributing to decreased soil fertility (Keesstra et al., 2016a; Khaledian et al., 2016a). These practices reduce soil organic carbon (Dawson and Smith, 2007; McCarl et al., 2007; Lal, 2009; Padmanabhan et al., 2013; Carr et al., 2015), soil structure (Cerdà, 2000; Carbonell-Bojollo et al., 2011; Bremenfeld et al., 2013), and increase soil compaction (Soane, 1990; Défossez et al., 2014) and erosion (GarcíaDíaz et al., 2016; Keesstra et al., 2016b; Rodrigo Comino et al., 2016). Excessive nitrogen fertilization often leads to soil acidification (Haynes and Swift, 1986; Juo et al., 1995; Horswill et al., 2008; Guo et al., 2010), reducing the availability of important elements for plant nutrition such as calcium, phosphorous and potassium (Blake et al., 1994; Horswill et al., 2008; Guo et al., 2010; Tang et al., 2011) and producing negative impacts on human health (Brevik and Sauer, 2015). Intense soil irrigation increases the concentration of salts (Quadir et al., 2004; Ouni et al., 2013; Wichelns and Qadir, 2015; Zewdu et al., 2015), especially in semiarid, arid, and coastal regions (Akhter et al., 2004; Singh et al., 2013; Ranjbal and Jajali, 2016). All these practices contribute to land degradation.

Soil chemical elements have a high spatial variability, especially in agricultural areas. For the application of sustainable soil management practices, it is essential to know the spatial distribution of soil properties to be able to identify areas that require intervention and the level at which those interventions are needed. The spatial variability of soil nutrients is affected by parent material characteristics, topography, climate, vegetation, time and anthropogenic activities (Fenton and Lauterbach, 1998; Johnson et al., 2000; Umali et al., 2012; Keesstra et al., 2016; Mulder et al., 2016). Several studies have investigated the spatial variability of soil pH (Robinson and Metternicht, 2006; Fu et al., 2010; Bogunovic et al., 2014; Behera and Shukla, 2015), organic matter (Bogunovic et al., 2014; Behera and Shukla, 2015; Yang et al., 2016a), electrical conductivity (EC) (Robinson and Metternicht, 2006; Heilig et al., 2011; Behera and Shukla, 2015; Ranjbar and Jalali, 2016), phosphorus (Fu et al., 2010; Romic et al., 2012; Bogunovic et al., 2014; Behera et al., 2016; Wilson et al., 2016) and 
potassium (Fu et al., 2010; Bogunovic et al., 2014; Behera and Shukla, 2015). A good understanding of soil properties distribution will contribute to better soil management in agricultural areas (Brevik et al., 2003). This is very important for farmers to make sustainable use of their lands.

Geostatistical methods are widely employed to assess the spatial distribution of soil properties in agricultural areas (Robinson and Metternicht, 2006; Fu et al., 2013; De Paz et al., 2015) and contribute to better land use management (Nael et al., 2004; Liu et al., 2016). There are many different univariate kriging methods used with soil variables (e.g. ordinary kriging, disjunctive kriging, indicator kriging). The models and maps produced by these techniques show the spatial variation of the variable of interest, but ignore interrelations with other environmental variables (co-variates) at the site (Lv et al., 2013). The use of auxiliary variables is advantageous to estimate the variable of interest during the analysis because it allows the analyst to determine if the spatial distribution of a determined variable is dependent upon other(s). These analyses are carried out using hybrid methods, such as co-kriging (Wen et al., 2015). The use of auxiliary variables normally increases the accuracy of the spatial predictions as observed in previous works (Stein and Corsten, 1991; Zhang et al., 1992; Yang et al., 2016b; Ceddia et al., 2015; Chen et al., 2016). Nevertheless, several works observed that the use of co-variates did not improve the accuracy of the interpolation (Martínez-Cob, 1996; Castrignano et al., 2011; Ceddia et al., 2015). This lack of improvement was attributed to the lack of or low correlation between the predictor(s) and the predicted variable. It follows that the performance of successful co-kriging depends on the use of proper auxiliary variables. The production of accurate maps is necessary for sustainable land management of agricultural areas. They will be the basis for restoration of degraded areas, and thus for a proper investment of the resources available, therefore it is essential that they be as accurate as possible (Brevik et al., 2016; Pereira et al., in press). In this context, it is important to investigate different co-variates and compare them in order to identify the least biased predictors that can be used to produce the best map to assist in land management. The aim of this work was to study the spatial 
distribution of soil $\mathrm{pH}$, soil organic matter (OM), plant available phosphorus (AP), potassium (AK), and electrical conductivity (EC) in the soils of a Croatian organic farm using geostatistical methods. The specific objectives of this paper are: (i) to assess the correlations among soil properties, (ii) to examine the spatial structure and variability of soil properties through semivariogram modelling, (iii) test several univariate and multivariate geostatistical techniques to find the best predictor for the studied soil properties (iv) and map the spatial distribution of soil properties using the most accurate model.

\section{Materials and Methods}

\subsection{Study area}

The study area is located on the Istria peninsula $\left(45^{\circ} 3^{\prime} \mathrm{N} ; 14^{\circ} 2^{\prime} \mathrm{I}\right.$; average elevation $-2 \mathrm{~m}$ below sea level), with a total area of 182 ha, divided into several parts by river channels (Fig. 1). The elevation decreases from north to south. A large part of the study area is below sea level and this necessitates pumping and draining excess water. A dam covers the south area and prevents the penetration of sea water into the valley. This land had been abandoned for at least two decades and covered with natural grasses and cane before cultivation began in 2015. The climate of the study area is Mediterranean. Mean annual temperature ranged from $12.2{ }^{\circ} \mathrm{C}$ to $15.2{ }^{\circ} \mathrm{C}$ and the average annual precipitation varied from $476 \mathrm{~mm}$ to $1444 \mathrm{~mm}$ between 1978 and 2014. Soils over the majority of the study area are classified as silty clay loam Anthrosols, while silty loam Colluvium soils and Gleysoils are found in some areas (Table 1).

\subsection{Sampling design and laboratory analyses}

One hundred eighty-two soil samples $(0-30 \mathrm{~cm})$ were collected during July of 2015 . The study area was divided into a regular grid with each box within the grid being approximately $100 \mathrm{x}$ $100 \mathrm{~m}$ (Fig. 1). A Trimble Geo 7X GPS with $10 \mathrm{~cm}$ accuracy was used to record the georeferenced coordinates. Each soil sample corresponds to a composite of subsamples taken from 15-20 
points from a diameter of $30 \mathrm{~m}$. Composite sampling is often used to overcome small scale variability of soil properties in order to mitigate outliers and extremes that may occur if investigators used individual samples for mapping an area of interest. Individual samples were mixed in a bucket and taken to the laboratory for analysis. This methodology was used in previous works (Sollitto et al., 2010; Winowiecki et al., 2016). Soil samples were air dried in the laboratory for seven days at room temperature and sieved with a $2 \mathrm{~mm}$ mesh. Soil $\mathrm{pH}$ was determined using the electrometric method in a 1:2.5 (w/v) soil:solution ratio with a Beckman pH-meter $\Phi 72$ in a $\mathrm{KCl}$ solution. Electrical conductivity (EC) was calculated at $25{ }^{\circ} \mathrm{C}$ on soil:water (1:5) extract according to HRN ISO 11265:2004. Soil OM was determined by a wet combustion procedure (Walkley and Black, 1934). Available $\mathrm{P}$ and $\mathrm{K}$ were extracted by ammonium lactate solution (Egner et al., 1960) and detected by spectrophotometry and flame photometry.

Insert: Figure 1 and Table 1

\subsection{Statistical analysis}

Some descriptive analyses were carried out, such as minimum, maximum, arithmetic mean, standard deviation (SD), coefficient of variation (CV), kurtosis (Kur) and skewness (Skew). Shape parameters indicated non-normality of data distributions, while the presence of high skewness indicates serious departure from normality (Webster, 2001). In order to meet normality requirements, the normal distribution was tested using the Kolmogorov-Smirnov test. Data was considered normally distributed at a $p>0.05$. If the original data did not respect the Gaussian distribution, a logarithmic (log) and Box-Cox transformation was carried out (Pereira et al., 2015). Normality and asymmetry of datasets is desirable because non-normality can have negative implications for geostatistical analysis (Kerry and Oliver, 2007). The Pearson correlation coefficient was calculated to examine correlation among the variables. Significant 
correlations were considered at a $\mathrm{p}<0.05$. Statistical analyses of correlations were performed with SAS software (version 9.3.).

\subsection{Geostatistical Analysis}

The spatial pattern of the studied variables was assessed with experimental semivariogram modelling, which is calculated according to the following formula:

$$
\gamma(h)=\frac{1}{2 N(h)} \sum_{i=1}^{N(h)}[Z(x i)-Z(x i+h)]^{2}
$$

where $\gamma(h)$ is the semivariance at given distance $h ; Z(x i)$ is the value of the variable $Z$ at the $x i$ location and $N(h)$ is the number of pairs of sample points separated by the lag distance $h$. Values were calculated for each possible pair of observation points and the mean values of the semivariance were displayed for chosen distance intervals to produce the experimental semivariogram (Isaaks and Srivastava, 1989).

In this study, semivariograms were checked for anisotropy to calculate the directional semivariograms. According to previous works, the number of samples required to reliably identify the presence of anisotropy is more than 150 (Webster and Oliver, 2007; Robinson and Metternicht, 2006; Pereira et al., 2013).

The spatial dependence of variables was assessed using the nugget effect and nugget/sill ratio. A ratio $<25$ shows a strong dependence, $25-75$ a moderate dependence, and $>75 \%$ a weak dependence (Cambardella et al., 1994). Several geostatistical techniques were tested to analyse the spatial variability of $\mathrm{pH}, \mathrm{EC}, \mathrm{OM}, \mathrm{AP}$ and $\mathrm{AK}$, such as ordinary kriging $(\mathrm{OK})$, partially heterotopic co-kriging and isotopic co-kriging. Partially heterotopic co-kriging used the other soil variables as auxiliary variables, if significantly correlated with the predicted variable, while isotopic co-kriging used the distance from the sea (DFS) and distance from the river channels (DFC) as co-variates. 
Ordinary kriging is a widely used interpolation technique that estimates the values at unsampled locations by a weighted averaging of nearby samples. The correlations among neighbouring values were modelled as a function of the distance between the samples across the study area, defined by a variogram. Ordinary kriging methods have been widely used in spatial analysis (eg. Pereira et al., 2013; Ceddia et al., 2015). An alternative to kriging is co-kriging, a specific method of analysis that includes auxiliary information incorporated into the estimation at un-sampled locations using the spatial correlation of the primary and secondary variables (Goovaerts, 1998).

The assessment criteria for the spatial models was carried out with the leave-one-out crossvalidation method, which estimates the sampling point from the surrounding samples. From the errors produced (observed-predicted) we calculated the Mean Error (ME) and the Root Mean Square Error (RMSE) according to the following formulas:

Mean error (ME)

$$
M E=\frac{1}{N} \sum_{i=1}^{n}\{Z(X i)-\hat{\mathrm{Z}}(X i)\}
$$

Root mean square error (RMSE):

$$
R M S E=\sqrt{\frac{1}{N} \sum_{i=1}^{n}\{Z(X i)-\hat{\mathrm{Z}}(X i)\}^{2}}
$$

Where: $Z(X i)$ is the observed value, $(X i)$ is the predicted value and $N$ is the number of samples. The most accurate model is the one with the lowest RMSE. For an easier comparison of the accuracy of cokriging models, relative improvement (RI) of cokriging over ordinary kriging was calculated with the following equation:

$$
R I=\frac{R M S E(O K)-R M S E(C o K)}{R M S E(O K)} \times 100
$$


Where RMSE(CoK) and RMSE(OK) represent the RMSE values of the CoKriging and ordinary kriging methods, respectively, obtained with the leave-one-out cross validation procedure. Spatial analysis was carried out and maps made using ArcGIS 10.1.

\section{Results and Discussion}

\subsection{Descriptive statistics}

The descriptive statistics for the soil chemical properties in the agricultural soils are presented in Table 2. According to the Kolmogorov-Smirmov test the $\mathrm{pH}$ and AK data were normally distributed, while OM data followed the Gaussian distribution after a Box-Cox transformation. Electric conductivity and AP data did not respect normality after logarithmic or Box-Cox transformations. For modelling purposes, we used Box-Cox transformed EC and AP data because it was the closest to a normal distribution. In previous works where data failed to respect normality the same criteria has been used (Sharma et al., 2011; Pereira et al., 2015). With the exception of soil $\mathrm{pH}$, the data was very heterogeneous. The soil was alkaline and this was attributed to its proximity to the sea and potential salt water intrusion into groundwater with the consequent deposition of salts on the soil by percolation; this process is also likely responsible for the high EC in the soil. This has been observed in previous studies in the region (Vidaček, 1977) and other deltas in the Adriatic Sea (Romic et al., 2012). Environments where evaporation exceeds precipitation causes upward movement of dissolved alkaline salts from the shallow ground water. This phenomenon was reported in alluvial soils on the Yellow River delta (Fan et al., 2012; He et al., 2015), delta area of the Nestos River in Greece (Gkiougkis et al., 2015), the Rhône delta in France (De Montety et al., 2008), and Nile delta in Egypt (Elbasiouny et al., 2014) but occurs along significant parts of all coastal areas on Earth (Li et al., 2014). The spatial variability of $\mathrm{OM}, \mathrm{AP}$ and $\mathrm{AK}$ was moderate, while EC was high (Table 2). The values of CV in the Rasa River valley were consistent with those observed for similar rivers and coastal areas in the Mediterranean basin. Romic et al. (2012) reported similar results for the $\mathrm{CV}$ that ranged from $2.2 \%(\mathrm{pH})$ to $74.7 \%(\mathrm{AP})$ in the Neretva River basin. Nanos and Martín 
(2012) observed CV values of 85.9, 17.2 and $88.9 \%$ for soil $\mathrm{OM}, \mathrm{pH}$ and $\mathrm{EC}$, respectively in soils of the Duero River basin. The high variability in these properties may be attributed to the different impacts of sea, river channels and/or groundwater on the soil. Soil OM was low in the studied area, supporting previous works carried out in the Croatian coastal areas (Bašić, 2013). Differences in soil OM in the studied area were attributed to the microrelief and the position of the sampling points in relation to the river channels. The areas where the floodplain was high had the highest OM concentrations as observed in previous works (Villegas-Pangga et al., 2000; Eglin et al., 2008; Ceddia et al., 2015). Secondly, the investigated land had been abandoned for at least 20 years prior to the initiation of cultivation in 2015, which strongly influenced the functionality of the channels. Many of the smaller channels were buried and covered with reeds at the time of sampling, which affected the level of groundwater and duration of waterloging at the soil surface.

Insert: Table 2.

The spatial varibility of AP and AK was attributed to the unequal fertilization in the studied area prior to land abandonment. However, AK content was very high, while AP was low. The high availability of $\mathrm{K}$ is attributed to the neutral and alkaline $\mathrm{pH}$ values that increse the bioavailability of this element (Khaledian et al., 2016b; Pereira et al., 2017). The low availability of $P$ is due to the observed $\mathrm{pH}$ values ( $>7$ ), which imobilized $\mathrm{P}$. The maximum bioavailability values of $\mathrm{P}$ are observed at pH values around 6.5 (Sharpely, 2000; Pereira et al., 2014).

\subsection{Correlation between soil parameters}

The correlation coefficient results are shown in Table 3. Soil pH was positively correlated with EC, OM and AK and negatively with AP. Electrical conductivity was positively correlated with OM and AK and negatively with AP, and soil OM was negatively correlated with AP and positively with AK. Distance from the sea was significantly negatively correlated with $\mathrm{pH}, \mathrm{EC}, \mathrm{OM}$ and $\mathrm{AK}$ 
and positively with AP. No significant correlations were observed between the studied variables and DFC. Our results support the findings of Behera and Shukla (2015), who found that soil pH has positive and significant relationships with soil exchangeable $\mathrm{K}$ and $\mathrm{OM}$ in cropped soils. The same authors found positive and significant correlations of soil OM with EC. Ranjbar and Jalali (2016) identified a strongly positive relationship between $\mathrm{pH}$ and $\mathrm{EC}$ in an agricultural field in western Iran. Romic et al. (2012) found a negative and significant relationship between soil pH and $\mathrm{EC}, \mathrm{OM}$ and $\mathrm{AP}$, and a positive and significant relationship between soil $\mathrm{OM}$ and $\mathrm{AK}$ in the Neretva River estuary. Li et al. (2007) observed significant positive correlations between soil EC and AK and negative significant correlations between EC and AP in the coastal saline region near Caoe River, China. The same authors reported negative correlations between $\mathrm{pH}$ and AP and positive between $\mathrm{pH}$ and AK. Land abandonment influenced the small channels functionality, ground water level and flood water movement in different year periods and consequently soil EC. High pH values are associated with high EC, OM and low AP (Bogunovic et al., 2015). Distance from the sea had a negative correlation with soil $\mathrm{pH}, \mathrm{EC}, \mathrm{OM}$ and $\mathrm{AK}$, showing the influence of salt water and/or breeze on these parameters. Wang et al. (2014) also observed a negative correlation between the distance to the sea and $\mathrm{pH}$ and EC. However, the negative correlation between DFS and organic matter does not agree with the results of previous works, which observed that OM increases with the distance from the coast (Morrissey et al., 2014; Wang et al., 2014). This may be attributed to watterlogging and increased salinity in the proximity of the sea. This affects decomposition rate by creating reduced microbial activity compared to areas that are at greater distance from the sea and have less saline soils and better conditions for microbial activity. Salinity increases the levels of AK in the soil and decreases the amount of AP, as observed by Iqbal (2016). This dynamic is also due to pH levels, as discussed in the previous section.

Insert: Table 3 . 


\subsection{Geostatistical analysis}

Spatial correlation for soil pH, EC, OM and AP was high in the directions of 154, 157, 60 and 175, respectively. Soil AK showed no anisotropy (Table 4; Fig 2). The spherical model was the most accurate to predict soil pH variability (Fig 2a), Gaussian was best for EC (Fig 2b), while OM, AK and AP were best fitted with an exponential model (Fig 2c, d, e). The nugget effect was residual in all cases (Table 4), showing that the small scale variance was minimal and the number of samples was adequate to measure the spatial variability of the studied variables. One sample per ha was representative to analyse the spatial variability of the studied elements in the area of interest. The impact of the outliers on the nugget effect was reduced by the data transformations. Previous works demonstrated that nugget usually occurs as a consequence of limited sample numbers, small-scale variance and the existence of outliers (e.g. McGrath and Zhang, 2003; Bogunovic et al., 2014; Pereira et al., 2015). The spatial dependence was high for soil pH, EC, and AK and moderate for OM and AP (Table 4). These results showed that the variables studied have a specific spatial pattern. Spatial correlation was high for soil EC and low for soil AP. Kerry and Oliver (2004) indicated that the variables range may be considered a guide for choosing future sampling intervals. According to the authors, the sample interval should be less than half the variogram range. All ranges were higher than the sampling interval $(100 \mathrm{~m})$, confirming that the sampling interval was appropriated to measure the spatial variability of the properties studied.

Insert: Table 4 and Figure 2.

\subsection{Performance of geostatistical interpolation methods and spatial distribution}

The results of the geostatistical techniques tested for soil $\mathrm{pH}, \mathrm{EC}, \mathrm{OM}, \mathrm{AP}$ and $\mathrm{AK}$ are shown in

Table 5. Distance from the sea was not used as an auxiliary variable since we did not identify a significant correlation with the estimated variables (Table 3). Amongst the tested geostatistical techniques, the most accurate technique for soil pH and EC was CoK_EC and CoK_DFS, 
respectively. The least accurate technique for $\mathrm{pH}$ was CoK_DFS and for EC was OK. The most precise method for OM was CoK_pH and the least accurate method was CoK_AK. CoK_DFS proved to be most accurate method for AP and the least accurate method was CoK_AK, while for AK the most accurate method was CoK_OM and the least accurate was CoK_DFS. These results indicate that the auxiliary variables increased the accuracy of the estimations, as was also observed in previous works (Chen et al., 2016; Guan et al., 2017). The spatial distribution of pH was best predicted with EC as an auxiliary variable, which reflects the correlation observed between the two properties. The best co-variate to estimate both EC and AP was the distance to the sea, showing the importance of the salt transported by wind and/or influence of salt percolation as a consequence of ocean water intrusion into ground water on EC levels and AP. As mentioned above, the distance to the sea has a significant negative correlation with EC, while the correlation with AP was positive (Table 3). The spatial distribution of OM was best estimated with $\mathrm{pH}$ as an auxiliary variable, as they had a significant positive correlation. As mentioned before this may be related to the impacts of soil salinity on organic matter decomposition.

The maps produced from the most accurate techniques are shown in Fig. 3. The soil $\mathrm{pH}$ and salinity maps showed that the most alkaline and saline soils were located in the southern part of the study area close to the sea. These areas have the lowest terrain and the highest water table. Poor drainage due to land abandonment influenced the higher groundwater mineralisation, which is reflected in the higher EC at similar locations and thus higher content of base cations that raise soil pH (Qadir et al., 2000; Fan et al., 2012). Unusually high levels of salinity and soil $\mathrm{pH}$ were observed in north-eastern parcels and can be explained by the clogged larger channel through which the water overflows onto land parcels. During intense southern winds, sea level is high causing deep penetration of seawater up the Rasa River and other large channels. At this particular location, seawater probably intrudes into smaller channels within the embankment which affects the rise in salinity and thus $\mathrm{pH}$ level. The maps of soil $\mathrm{pH}$ and EC show a spatial correlation, observed previously in the Pearson correlation coefficient (Table 3). The soils of the 
southeast corner of this study area are rich in OM content. This can be explained by the former placement of the river, before intervention (Fig. 4).

Insert: Table 5 and Figure 3; Figure 4.

\section{Conclusion}

The soils studied had high pH, EC, OM and AK levels, while AP content was low. Soil pH, EC, OM and AK were significantly positively correlated. These variables had a significantly negative correlation with AP. The spatial variability was very high for soil EC and low for $\mathrm{pH}$. The best fit models for $\mathrm{OM}, \mathrm{AK}$ and $\mathrm{AP}$ were exponential, while for $\mathrm{pH}$ and $\mathrm{EC}$ they were spherical and Gaussian, respectively. The spatial dependence and range was high for AK and lower for AP. The best spatial predictors for EC and AP were Cok_DFS, while for pH, OM and AK they were Cok_EC, Cok_pH and Cok_OM, respectively. The use of co-variates improved the prediction of the studied variables, although the differences among the tested methods were not substantial. Soil pH, EC, $\mathrm{OM}$ and $\mathrm{AK}$ had high levels in the southern and eastern parts of the area of interest, while we observed the opposite trend for AP.

\section{Acknowledgements}

The authors are grateful for the financial support of organic crop firm OPG Chiavalon. E.C. Brevik was partially supported by the National Science Foundation under Grant Number IIA-1355466 during this project. We also acknowledge the important contributions of two anonymous reviewers that improved the quality of this manuscript.

\section{References}

Akhter, J., Murray, R., Mahmood, K., Malik, K. A., Ahmed, S. (2004). Improvement of degraded physical properties of a saline-sodic soil by reclamation with kallar grass (Leptochloa fusca). Plant and Soil, 258(1), 207-216. DOI: 10.1023/B:PLS0.0000016551.08880.6b 
Bašić, F. (2013). The soils of Croatia. Springer.

Behera, S. K., Shukla, A. K. (2015). Spatial distribution of surface soil acidity, electrical conductivity, soil organic carbon content and exchangeable potassium, calcium and magnesium in some cropped acid soils of India. Land Degradation \& Development, 26(1), 71-79. DOI: 10.1002/ldr.2306

Behera, S.K., Suresh, K., Rao, B. N., Kumar Mathur, R., Shukla, A. K., Manorama, K., Ramachandrudu, K., Harinarayana, P., Prakash, C. (2016). Spatial variability of some soil properties varies in oil palm (Elaeis guineensis Jacq.) plantations of west coastal area of India. Solid Earth, 7(3), 979-993. DOI: 10.5194/se-7-979-2016

Blake, L., Johnston, A. E., Goulding, K. W. T. (1994). Mobilization of aluminium in soil by acid deposition and its uptake by grass cut for hay-a Chemical Time Bomb. Soil Use and Management, 10(2), 51-55. DOI: 10.1111/j.1475-2743.1994.tb00458.x

Bogunovic, I., Mesic, M., Zgorelec, Z., Jurisic, A., Bilandzija, D. (2014). Spatial variation of soil nutrients on sandy-loam soil. Soil and Tillage Research, 144, 174-183. DOI: 10.1016/j.still.2014.07.020

Bogunovic, I., Kisic, I., Jurisic, A. (2015). Influence of wildfire and fire suppression by seawater on soil properties. Applied Ecology and Environmental Research, 13(4), 1157-1169. DOI: dx.doi.org/10.15666/aeer/1304_11571169

Bremenfeld, S., Fiener, P., Govers, G. (2013). Effects of interrill erosion, soil crusting and soil aggregate breakdown on in situ CO2 effluxes. Catena, 104, 14-20. DOI: 10.1016/j.catena.2012.12.011

Brevik, E.C., Calzolari, C.C., Miller, B.A., Pereira, P., P., Kabala, C., Baumgarten, A., Jordan, A. (2016). Soil mapping, classification, and pedological modelling: History and future directions. Geoderma, 264, 256-274. DOI: 10.1016/j.geoderma.2015.05.017

Brevik, E.C., Fenton, T.E., Jaynes, D.B. (2003). Evaluation of the accuracy of a central Iowa soil survey and implications for precision soil management. Precision Agriculture, 4, 323334. 
Brevik, E.C., Sauer, T.J. (2015). The past, present, and future of soils and human health studies. SOIL, 1, 35-46. DOI:10.5194/soil-1-35-2015

Cambardella, C. A., Moorman, T. B., Parkin, T. B., Karlen, D. L., Novak, J. M., Turco, R. F., Konopka, A. E. (1994). Field-scale variability of soil properties in central Iowa soils. Soil Science Society of America Journal, 58(5), 1501-1511. DOI: 10.2136/sssaj1994.03615995005800050033x

Carbonell-Bojollo, R., González-Sánchez, E. J., Veróz-González, O., Ordóñez-Fernández, R. (2011). Soil management systems and short term CO2 emissions in a clayey soil in southern Spain. Science of the Total Environment, 409(15), 2929-2935. DOI: 10.1016/j.scitotenv.2011.04.003

Carr, P.M., Brevik, E.C., Horsley, R.D., Martin, G.B. (2015). Long-term no-tillage sequesters soil organic carbon in cool semi-arid regions. Soil Horizons 56(6), doi:10.2136/sh15-070016.

Castrignano, A., Buttafuoco, G., Comolli, R. (2011). Using digital elevation model to improve soil pH prediction in an alpine doline. Pedosphere, 21(2), 259-270. DOI: 10.1016/S10020160(11)60126-4

Ceddia, M. B., Villela, A. L. O., Pinheiro, É. F. M., Wendroth, O. (2015). Spatial variability of soil carbon stock in the Urucu River basin, Central Amazon-Brazil. Science of the Total Environment, 526, 58-69. DOI: 10.1016/j.scitotenv.2015.03.121

Cerdà, A. (2000). Aggregate stability against water forces under different climates on agriculture land and scrubland in southern Bolivia. Soil and Tillage Research, 57(3), 159-166. DOI: 10.1016/S0167-1987(00)00155-0

Chen, T., Chang, Q., Liu, J., Clevers, J. G. P. W., Kooistra, L. (2016). Identification of soil heavy metal sources and improvement in spatial mapping based on soil spectral information: A case study in northwest China. Science of the Total Environment, 565, 155-164. DOI: 10.1016/j.scitotenv.2016.04.163 
Dawson, J. J., Smith, P. (2007). Carbon losses from soil and its consequences for land-use management. Science of the Total Environment, 382(2), 165-190. DOI: 10.1016/j.scitotenv.2007.03.023

De Montety, V., Radakovitch, O., Vallet-Coulomb, C., Blavoux, B., Hermitte, D., Valles, V. (2008). Origin of groundwater salinity and hydrogeochemical processes in a confined coastal aquifer: case of the Rhône delta (Southern France). Applied Geochemistry, 23(8), 23372349. DOI: 10.1016/j.apgeochem.2008.03.011.

De Paz, J. M., Albert, C., Visconti, F., Jiménez, M. G., Ingelmo, F., Molina, M. J. (2015). A new methodology to assess the maximum irrigation rates at catchment scale using geostatistics and GIS. Precision Agriculture, 16(5), 505-531. DOI: 10.1007/s11119-0159392-y

Défossez, P., Richard, G., Keller, T., Adamiade, V., Govind, A., Mary, B. (2014). Modelling the impact of declining soil organic carbon on soil compaction: Application to a cultivated Eutric Cambisol with massive straw exportation for energy production in northern France. Soil and Tillage Research, 141, 44-54. DOI: 10.1016/j.still.2014.03.003

Eglin, T., Walter, C., Nys, C., Follain, S., Forgeard, F., Legout, A., Squividant, H. (2008). Influence of waterlogging on carbon stock variability at hillslope scale in a beech forest (Fougères forest-West France). Annals of Forest Science, 65(2), 1-10. DOI: 10.1051/forest:2007085

Egnér, H. A. N. S., Riehm, H., Domingo, W. R. (1960). Untersuchungen über die chemische Bodenanalyse als Grundlage für die Beurteilung des Nährstoffzustandes der Böden. II. Chemische Extraktionsmethoden zur Phosphor-und Kaliumbestimmung. Kungliga Lantbrukshögskolans Annaler, 26, 199-215.

Elbasiouny, H., Abowaly, M., Abu_Alkheir, A., Gad, A. (2014). Spatial variation of soil carbon and nitrogen pools by using ordinary Kriging method in an area of north Nile Delta, Egypt. Catena, 113, 70-78. DOI: 10.1016/j.catena.2013.09.008 
Fan, X., Pedroli, B., Liu, G., Liu, Q., Liu, H., Shu, L. (2012). Soil salinity development in the yellow river delta in relation to groundwater dynamics. Land Degradation \& Development, 23, 175-189. DOI: 10.1002/ldr.1071

Fenton, T.E., Lauterbach, M.A. (1998). Soil map unit composition and scale of mapping related to interpretations for precision soil and crop management in Iowa, in: Robert, P.C., Rust, R.H., Larson, W.E. (Eds.), Proceedings of the 4th International Conference on Precision Agriculture, edited by ASA, CSSA, SSSA, Madison, WI. pp. 239-251.

Fu, W., Tunney, H., Zhang, C. (2010). Spatial variation of soil nutrients in a dairy farm and its implications for site-specific fertilizer application. Soil and Tillage Research, 106(2), 185-193. DOI: 10.1016/j.still.2009.12.001

Fu, W., Zhao, K., Tunney, H., Zhang, C. (2013). Using GIS and Geostatistics to optimize soil phosphorous and magnesium sampling in temperate grassland. Soil Science, 178(5), 240-247. DOI: 10.1097/SS.0b013e31829d463b

García-Díaz, A., Allas, R. B., Gristina, L., Cerdà, A., Pereira, P., Novara, A. (2016). Carbon input threshold for soil carbon budget optimization in eroding vineyards. Geoderma, 271, 144-149. DOI: 10.1016/j.geoderma.2016.02.020

Gkiougkis, I., Kallioras, A., Pliakas, F., Pechtelidis, A., Diamantis, V., Diamantis, I., Ziogas, A., Dafnis, I. (2015). Assessment of soil salinization at the eastern Nestos River Delta, NE Greece. Catena, 128, 238-251. DOI: 10.1016/j.catena.2014.06.024

Goovaerts, P. (1998). Ordinary CoKriging revisited. Mathematical Geology, 30(1), 21-42. DOI: 10.1023/A:1021757104135

Guan, F., Xia, M., Tang, X., Fan, S. (2017) Spatial variability of soil nitrogen, phosphorous and potassium contents in Moso bamboo forests in Yong'an City, China. Catena, 150, 161172. DOI: $10.1016 /$ j.catena.2016.11.017

Guo, J. H., Liu, X. J., Zhang, Y., Shen, J. L., Han, W. X., Zhang, W. F., Christie, P., Goulding, K. W. T., Vitousek, P.M., Zhang, F. S. (2010). Significant acidification in major Chinese croplands. Science, 327(5968), 1008-1010. DOI: 10.1126/science.1182570 
Haynes, R. J., Swift, R. S. (1986). Effects of soil acidification and subsequent leaching on levels of extractable nutrients in a soil. Plant and Soil, 95(3), 327-336. DOI: 10.1007/BF02374613

He, B., Cai, Y., Ran, W., Zhao, X., Jiang, H. (2015). Spatiotemporal heterogeneity of soil salinity after the establishment of vegetation on a coastal saline field. Catena, 127, 129-134. DOI: $10.1016 /$ j.catena.2014.12.028

Heilig, J., Kempenich, J., Doolittle, J., Brevik, E.C., Ulmer, M. (2011). Evaluation of electromagnetic induction to characterize and map sodium-affected soils in the Northern Great Plains. Soil Survey Horizons, 52(3), 77-88. DOI: 10.2136/ssh2011-52-3-2

Horswill, P., O'Sullivan, O., Phoenix, G. K., Lee, J. A., Leake, J. R. (2008). Base cation depletion, eutrophication and acidification of species-rich grasslands in response to long-term simulated nitrogen deposition. Environmental Pollution, 155(2), 336-349. DOI: 10.1016/j.envpol.2007.11.006

HRN ISO 11265 (2004). Soil quality - Determination of the specific electrical conductivity

Iqbal, T. (2016) Rice straw amendment ameliorates harmful effect of salinity and increases nitrogen availability in a paddy soil. Journal of the Saudi Society of Agricultural Sciences. DOI: 10.1016/j.jssas.2016.11.002.

Isaaks, E. H., Srivastava, R. M. (1989). Applied geostatistics. Oxford University Press. New York.

Johnson, C. E., Ruiz-Mendez, J. J., Lawrence, G. B. (2000). Forest soil chemistry and terrain attributes in a Catskills watershed. Soil Science Society of America Journal, 64(5), 18041814. DOI: $10.2136 /$ sssaj2000.6451804x

Juo, A. S. R., Dabiri, A., Franzluebbers, K. (1995). Acidification of a kaolinitic Alfisol under continuous cropping with nitrogen fertilization in West Africa. Plant and Soil, 171(2), 245-253. DOI: 10.1007/BF00010278

Keesstra, S.D., Bouma, J., Wallinga, J., Tittonell, P., Smith, P., Cerdà, A., Montanarella, L., Quinton, J.N., Pachepsky, Y., van der Putten, W.H., Bardgett, R.D., Moolenaar, S., Mol, G., Jansen, B., Fresco, L.O. (2016a). The significance of soils and soil science towards realization of the 
United Nations Sustainable Development Goals. SOIL, 2, 111-128. DOI: 10.5194/soil-2$111-2016$

Keesstra, S., Pereira, P., Novara, A., Brevik, E. C., Azorin-Molina, C., Parras-Alcántara, L., Jordán, A., Cerdà, A. (2016b). Effects of soil management techniques on soil water erosion in apricot orchards. Science of the Total Environment, 551, 357-366. DOI: 10.1016/j.scitotenv.2016.01.182

Kerry, R., Oliver, M. A. (2004). Average variograms to guide soil sampling. International Journal of Applied Earth Observation and Geoinformation, 5(4), 307-325. DOI: 10.1016/j.jag.2004.07.005

Kerry, R., Oliver, M. A. (2007). Comparing sampling needs for variograms of soil properties computed by the method of moments and residual maximum likelihood. Geoderma, 140(4), 383-396. DOI: 10.1016/j.geoderma.2007.04.019

Khaledian, Y., Kiani, F., Ebrahimi, S., Brevik, E.C., Aitkenhead-Peterson, J. (2016a). Assessment and monitoring of soil degradation during land use change using multivariate analysis. Land Degradation and Development. doi: 10.1002/ldr.2541.

Khaledian, Y., Pereira, P., Brevik, E., Pundyte, N., Paliulis, D. (2016b) The influence of organic carbon and $\mathrm{pH}$ on heavy metals, potassium and magnesium in Lithuanian podzols. Land Degradation and Development. DOI: 10.1002/ldr.2638

Lal, R. (2009). Challenges and opportunities in soil organic matter research. European Journal of Soil Science, 60(2), 158-169. DOI: 10.1111/j.1365-2389.2008.01114.x

Li, Y., Shi, Z., Li, F., Li, H. Y. (2007). Delineation of site-specific management zones using fuzzy clustering analysis in a coastal saline land. Computers and Electronics in Agriculture, 56(2), 174-186. DOI: 10.1016/j.compag.2007.01.013

Li, J., Pu, L., Zhu, M., Zhang, J., Li, P., Dai, X., Xu, Y., Liu, L. (2014). Evolution of soil properties following reclamation in coastal areas: A review. Geoderma, 226, 130-139. DOI: 10.1016/j.geoderma.2014.02.003 
Liu, R., Xu, F., Yu, W., Shi, J., Zhang, P., Shen, Z. (2016). Analysis of field-scale spatial correlations and variations of soil nutrients using geostatistics. Environmental Monitoring and Assessment, 188(2), 1-10. DOI: 10.1007/s10661-016-5130-9

Lv, J., Liu, Y., Zhang, Z., Dai, J. (2013). Factorial kriging and stepwise regression approach to identify environmental factors influencing spatial multi-scale variability of heavy metals in soils. Journal of Hazardous Materials, 261, 387-397. DOI: 10.1016/j.jhazmat.2013.07.065

Martínez-Cob, A. (1996). Multivariate geostatistical analysis of evapotranspiration and precipitation in mountainous terrain. Journal of Hydrology, 174(1), 19-35. DOI: $10.1016 / 0022-1694(95) 02755-6$

McCarl, B. A., Metting, F. B., Rice, C. (2007). Soil carbon sequestration. Climatic Change, 80(1), 13. DOI: $10.1007 / \mathrm{s} 10584-006-9174-7$

McGrath, D., Zhang, C. (2003). Spatial distribution of soil organic carbon concentrations in grassland of Ireland. Applied Geochemistry, 18(10), 1629-1639. DOI: 10.1016/S08832927(03)00045-3

Mulder, V.L., Lacoste, M., Richer-de-Forxges, A.C., Arrouays, D. (2016) GlobalSoilMap France: High resolution spatial modelling the soils of France up to two meter depth. Science of the Total Environment, 573(1), 1352-1369. DOI:10.1016/j.scitotenv.2016.07.066

Morrissey, E. M., Gillespie, J. L., Morina, J. C., Franklin, R. B. (2014). Salinity affects microbial activity and soil organic matter content in tidal wetlands. Global Change Biology, 20(4), 1351-1362. DOI: 10.1111/gcb.12431

Nael, M., Khademi, H., Hajabbasi, M. A. (2004). Response of soil quality indicators and their spatial variability to land degradation in central Iran. Applied Soil Ecology, 27(3), 221232. DOI: 10.1016/j.apsoil.2004.05.005

Nanos, N., Martín, J.A.R. (2012). Multiscale analysis of heavy metal contents in soils: spatial variability in the Duero river basin (Spain). Geoderma, 189, 554-562. DOI: 10.1016/j.geoderma.2012.06.006 
Ouni, Y., Lakhdar, A., Scelza, R., Scotti, R., Abdelly, C., Barhoumi, Z., Rao, M. A. (2013). Effects of two composts and two grasses on microbial biomass and biological activity in a saltaffected soil. Ecological Engineering, 60, 363-369. DOI: 10.1016/j.ecoleng.2013.09.002

Qadir, M., Ghafoor, A., Murtaza, G. (2000). Amelioration strategies for saline soils: a review. Land Degradation \& Development, $\quad 11(6), \quad 501-521 . \quad$ DOI: $\quad 10.1002 / 1099-$ 145X(200011/12)11:6<501::AID-LDR405>3.0.CO;2-S

Qadir, M., Oster, J. D. (2004). Crop and irrigation management strategies for saline-sodic soils and waters aimed at environmentally sustainable agriculture. Science of the Total Environment, 323(1), 1-19. DOI: 10.1016/j.scitotenv.2003.10.012

Padmanabhan, E., Eswaran, H., Reich, P. F. (2013). Soil carbon stocks in Sarawak, Malaysia. Science of the Total Environment, 465, 196-204. DOI: 10.1016/j.scitotenv.2013.03.024

Pereira, P., Cerdà, A., Úbeda, X., Mataix-Solera, J., Martin, D., Jordán, A., Burguet, M. (2013). Spatial models for monitoring the spatio-temporal evolution of ashes after fire-a case study of a burnt grassland in Lithuania. Solid Earth, 4, 153. DOI: 10.5194/se-4-153-2013

Pereira, P., Úbeda, X., Martin, D., Mataix-Solera, J., Cerdà, A., Burguet, M. (2014). Wildfire effects on extractable elements in ash from a Pinus pinaster forest in Portugal. Hydrological Processes, 28(11), 3681-3690. DOI: 10.1002/hyp.9907

Pereira, P., Brevik, E., Munoz-Rojas, M., Miller, B., Smetanova, A., Depellegrin, D., Misiune, I., Novara, A., Cerda, A. Soil mapping and process modelling for sustainable land management. In: Pereira, P., Brevik, E., Munoz-Rojas, M., Miller, B. (Eds.) Soil mapping and process modelling for sustainable land use management. Elsevier (in press).

Pereira, P., Cerdà, A., Úbeda, X., Mataix-Solera, J., Arcenegui, V., Zavala, L. M. (2015). Modelling the Impacts of Wildfire on Ash Thickness in a Short-Term Period. Land Degradation \& Development, 26(2), 180-192. DOI: 10.1002/ldr.2195

Pereira, P., Cerdà, A., Martin, D., Úbeda, X., Depellegrin, D., Novara, A., Martínez-Murillo, J.F., Brevik, E.C., Menshov, O., Rodrigo Comino, J., Miesel, J. (2017). Short-term low-severity 
spring grassland fire impacts on soil extractable elements and soil ratios in Lithuania. Science of the Total Environment, 578, 469-475. doi:10.1016/j.scitotenv.2016.10.210

Ranjbar, F., Jalali, M. (2016). The combination of geostatistics and geochemical simulation for the site-specific management of soil salinity and sodicity. Computers and Electronics in Agriculture, 121, 301-312. DOI: 10.1016/j.compag.2015.12.010

Robinson, T. P., Metternicht, G. (2006). Testing the performance of spatial interpolation techniques for mapping soil properties. Computers and Electronics in Agriculture, 50(2), 97-108. DOI: 10.1016/j.compag.2005.07.003

Rodrigo Comino, J., Quiquerez, A., Follain, S., Raclot, D., Le Bissonnais, Y., Casalí, J., Giménez, R., Cerdà, A., Keesstra, S.D., Brevik, E.C., Pereira, P., Senciales, J.M., Seeger. M., Ruiz Sinoga, J.D., Ries, J.B. (2016). Soil erosion in sloping vineyards assessed by using botanical indicators and sediment collectors in the Ruwer-Mosel Valley. Agriculture, Ecosystems and Environment, 233, 158-170. DOI: 10.1016/j.agee.2016.09.009

Romic, D., Romic, M., Zovko, M., Bakic, H., Ondrasek, G. (2012). Trace metals in the coastal soils developed from estuarine floodplain sediments in the Croatian Mediterranean region. Environmental Geochemistry and Health, 34(4), 399-416. DOI: 10.1007/s10653-0129449-z

Sharma, P., Shukla, M. K., Mexal, J. G. (2011). Spatial Variability of Soil Properties in Agricultural Fields of Southern New Mexico. Soil Science, 176(6), 288-302. DOI: 10.1097/SS.0b013e31821c0dab

Sharpley, A. (2000): Phosphorus availability. In: Sumner, M.E. (ed.). Handbook of soil science. CRC, Boca Raton, Fla. D18- D38.

Singh, K., Singh, B., Singh, R.R. (2013). Effect of land rehabilitation on physicochemical and microbial properties of a sodic soil. Catena 109, 49-57. DOI: 10.1016/j.catena.2013.05.006 
Soane, B. D. (1990). The role of organic matter in soil compactibility: a review of some practical aspects. Soil and Tillage Research, 16(1), 179-201. DOI: 10.1016/01671987(90)90029-D

Sollitto, D., Romic, M., Castrignanò, A., Romic, D., Bakic, H. (2010). Assessing heavy metal contamination in soils of the Zagreb region (Northwest Croatia) using multivariate geostatistics. Catena, 80(3), 182-194. DOI: 10.1016/j.catena.2009.11.005

Stein, A., Corsten, L. C. A. (1991). Universal kriging and cokriging as a regression procedure. Biometrics, 47(2), 575-587.

Tang, C., Conyers, M.K., Nuruzzaman, M., Poile, G.J., Liu, D.L. (2011). Biological amelioration of subsoil acidity through managing nitrate uptake by wheat crops. Plant and Soil, 338, 383-397. DOI: $10.1007 / \mathrm{s} 11104-010-0552-6$

Umali, B. P., Oliver, D. P., Forrester, S., Chittleborough, D. J., Hutson, J. L., Kookana, R. S., Ostendorf, B. (2012). The effect of terrain and management on the spatial variability of soil properties in an apple orchard. Catena, 93, 38-48. DOI: 10.1016/j.catena.2012.01.010

Walkley, A., Black, I. A. (1934). An examination of the Degtjareff method for determining soil organic matter, and a proposed modification of the chromic acid titration method. Soil Science, 37(1), 29-38.

Wang, L., Coles, N., Wu, C., Wu, J. (2014) Effect of long-term reclamation on soil properties on a coastal plain, Southeast China. Journal of Coastal Research, 30, 661 - 669. DOI: 10.2112/JCOASTRES-D-13-00129.1

Webster, R. (2001). Statistics to support soil research and their presentations. European Journal of Soil Science, 52, 331-340. DOI: 10.1046/j.1365-2389.2001.00383.x

Webster, R., Oliver, M. A. (2007). Geostatistics for environmental scientists, second edition. John Wiley \& Sons, London.

Wen, W., Wang, Y., Yang, L., Liang, D., Chen, L., Liu, J., Zhu, A. X. (2015). Mapping soil organic carbon using auxiliary environmental covariates in a typical watershed in the Loess 
Plateau of China: a comparative study based on three kriging methods and a soil land inference model (SoLIM). Environmental Earth Sciences, 73(1), 239-251. DOI: $10.1007 / \mathrm{s} 12665-014-3518-9$

Wichelns, D., Qadir, M. (2015). Achieving sustainable irrigation requires effective management of salts, soil salinity, and shallow groundwater. Agricultural Water Management, 157, 3138. DOI: 10.1016/j.agwat.2014.08.016

Vidaček Ž. (1977). General Soil Map. Soils of Pazin 3 section. Pedological map of FR Croatia (in Croatian)

Villegas-Pangga, G., Blair, G., Lefroy, R. (2000). Measurement of decomposition and associated nutrient release from straw (Oryza sativa L.) of different rice varieties using a perfusion system. Plant and Soil, 223(1-2), 1-11. DOI: 10.1023/A:1004777911428

Wilson, H. F., Satchithanantham, S., Moulin, A. P., Glenn, A. J. (2016). Soil phosphorus spatial variability due to landform, tillage, and input management: A case study of small watersheds in southwestern Manitoba. Geoderma, 280, 14-21. DOI: 10.1016/j.geoderma.2016.06.009

Winowiecki, L., Vågen, T. G., Huising, J. (2016). Effects of land cover on ecosystem services in Tanzania: A spatial assessment of soil organic carbon. Geoderma, 263, 274-283. DOI: 10.1016/j.geoderma.2015.03.010

Yang, P., Byrne, J. M., Yang, M. (2016a). Spatial variability of soil magnetic susceptibility, organic carbon and total nitrogen from farmland in northern China. Catena, 145, 92-98. DOI: 10.1016/j.catena.2016.05.025

Yang, Q., Luo, W., Jiang, Z., Li, W., Yuan, D. (2016b). Improve the prediction of soil bulk density by CoKriging with predicted soil water content as auxiliary variable. Journal of Soils and Sediments, 16(1), 77-84. DOI: 10.1007/s11368-015-1193-4

Zewdu, S., Suryabhagavan, K. V., Balakrishnan, M. (2015). Geo-spatial approach for soil salinity mapping in Sego Irrigation Farm, South Ethiopia. Journal of the Saudi Society of Agricultural Sciences. DOI: 10.1016/j.jssas.2014.12.003 
Zhang, R., Myers, D. E., Warrick, A. W. (1992). Estimation of the spatial distribution of soil chemicals using pseudo-cross-variograms. Soil Science Society of America Journal, 56(5), 1444-1452. DOI: 10.2136/sssaj1992.03615995005600050018x 
Fig. 1. Study area in Croatia and distribution of sampling sites.

Fig. 2. Directional semivariograms calculated for: a) soil $\mathrm{pH}, \mathrm{b}$ ) electrical conductivity, c) soil organic matter, and e) plant available phosphorus. The omnidirectional semivariogram is presented for d) plant available potassium.

Fig. 3. Spatial distribution maps according to the most accurate techniques: soil pH (CoK_DFC) and AK (CoK_OM) with original data; EC (CoK_DFC), OM (CoK_pH) and AP (CoK_DFS) with BoxCox transformed data.

Fig. 4. Evidence of the former position of the river, seen as the green area in a form of a crescent that runs through the centre part of the photograph. 


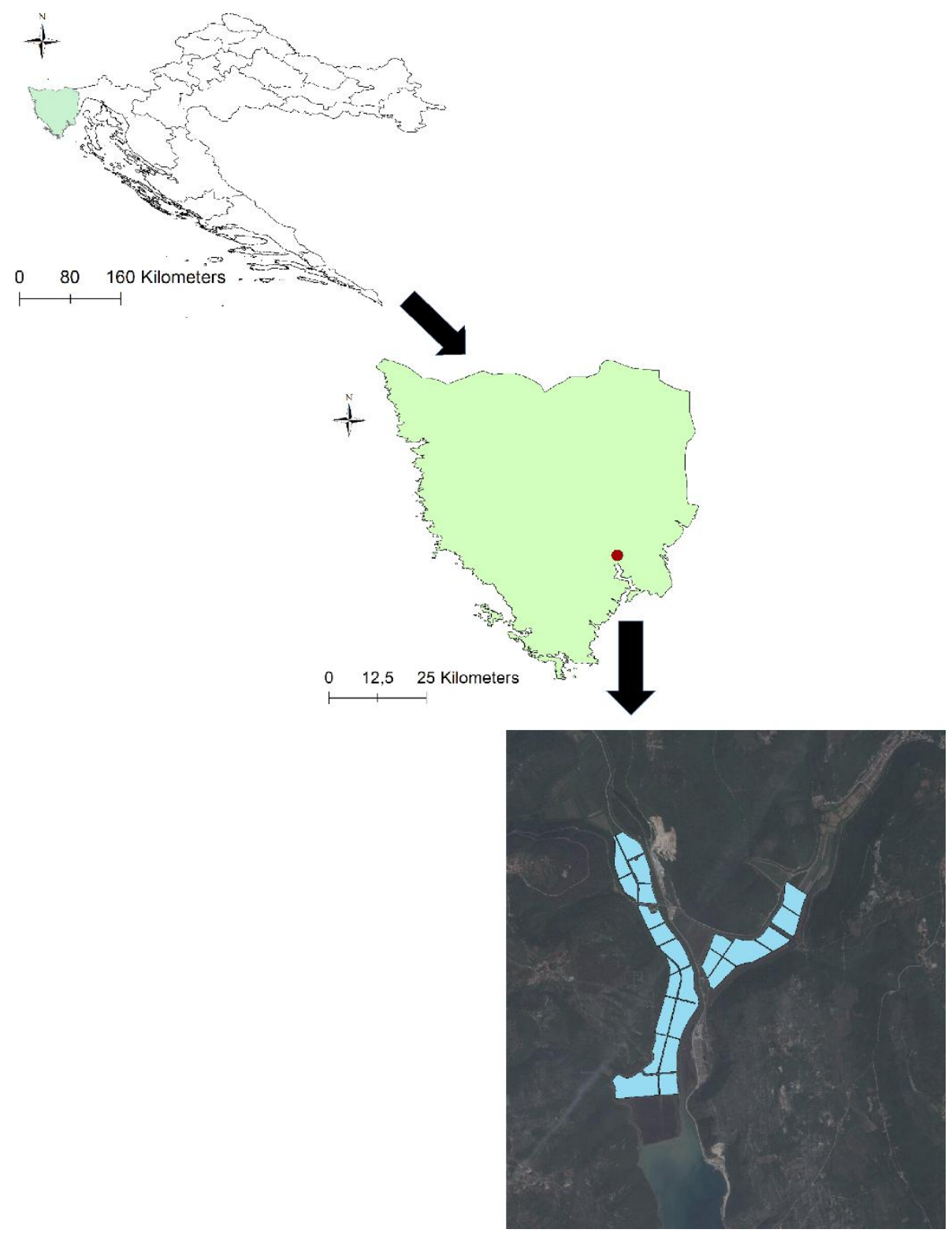

Fig. 1. Study area in Croatia and distribution of sampling sites.

(note: print in colour) 
a)

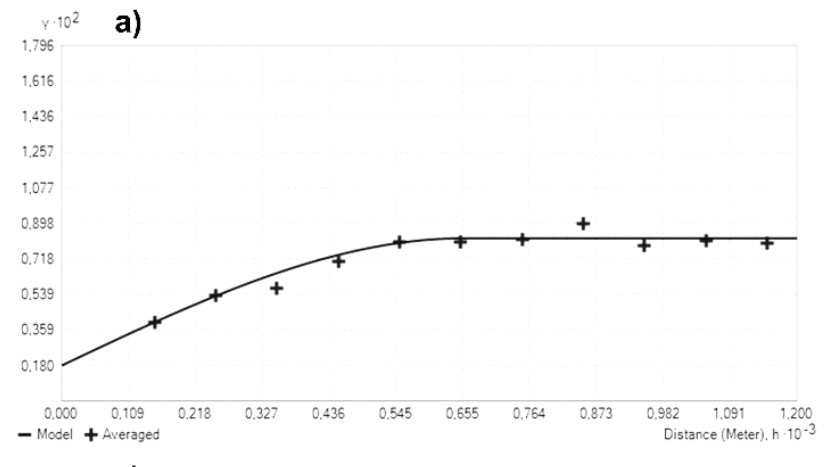

c)
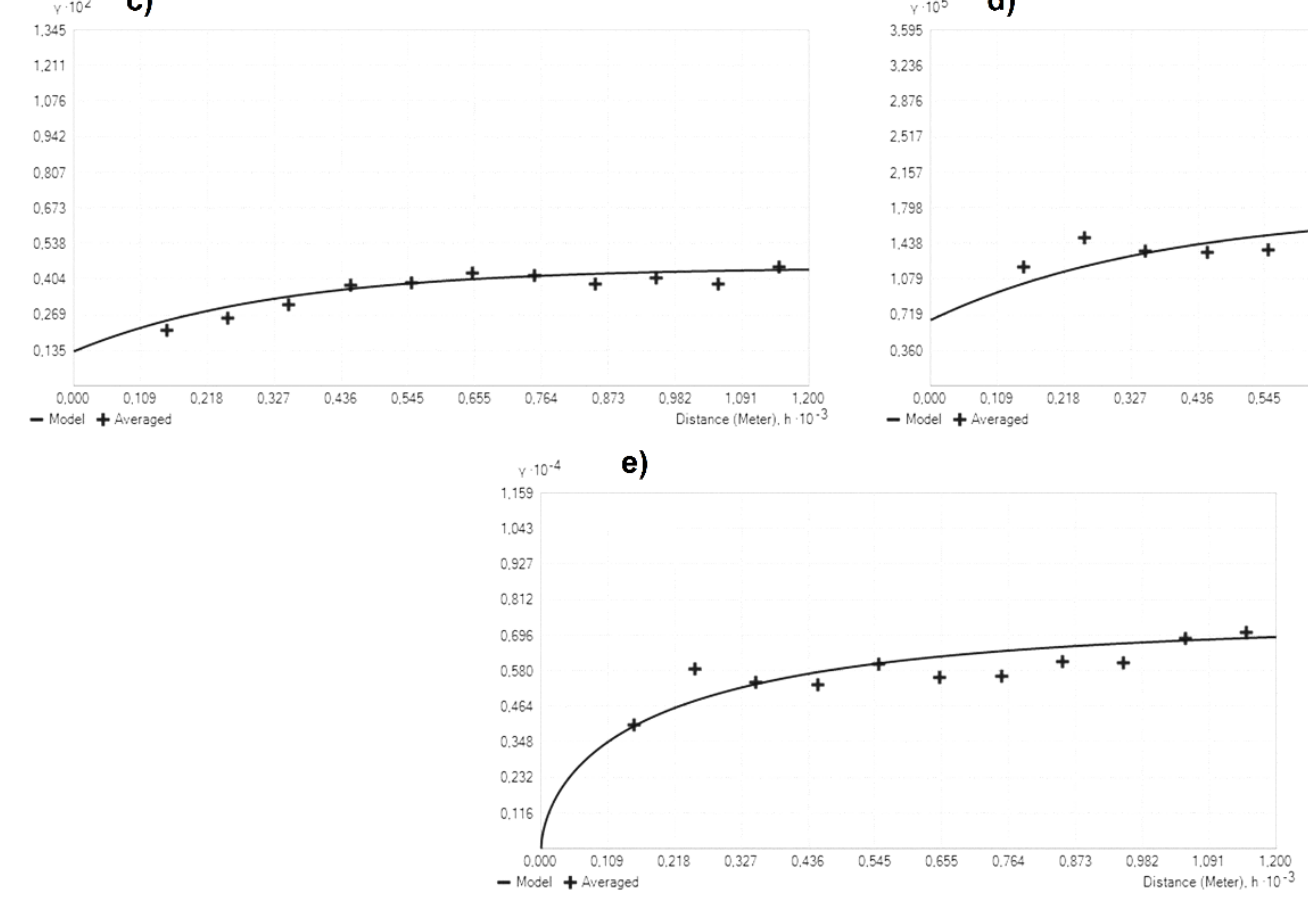

Fig. 2. Directional semivariograms calculated for: a) soil $\mathrm{pH}$, b) electrical conductivity, c) soil organic matter, and e) plant available phosphorus. The omnidirectional semivariogram is presented for d) plant available potassium.
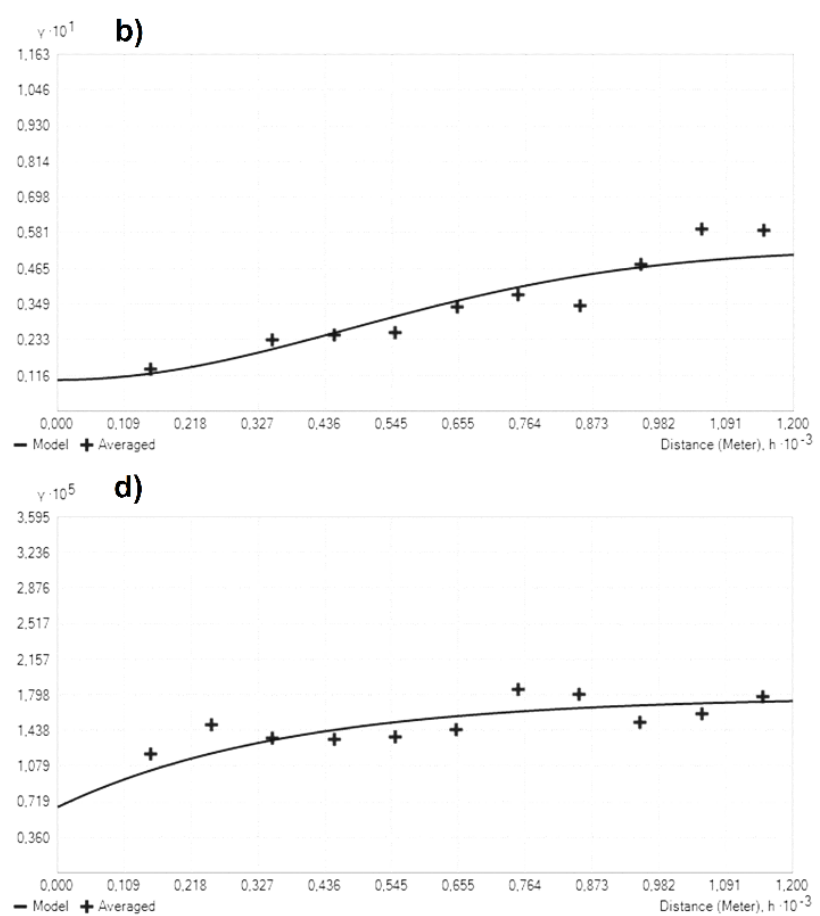

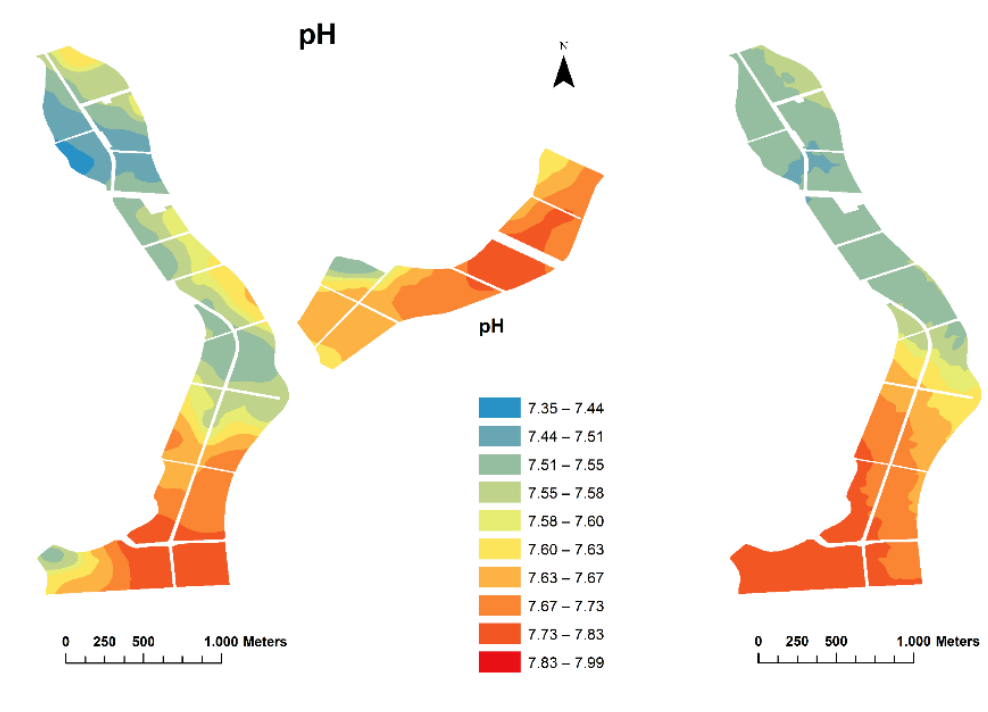

EC
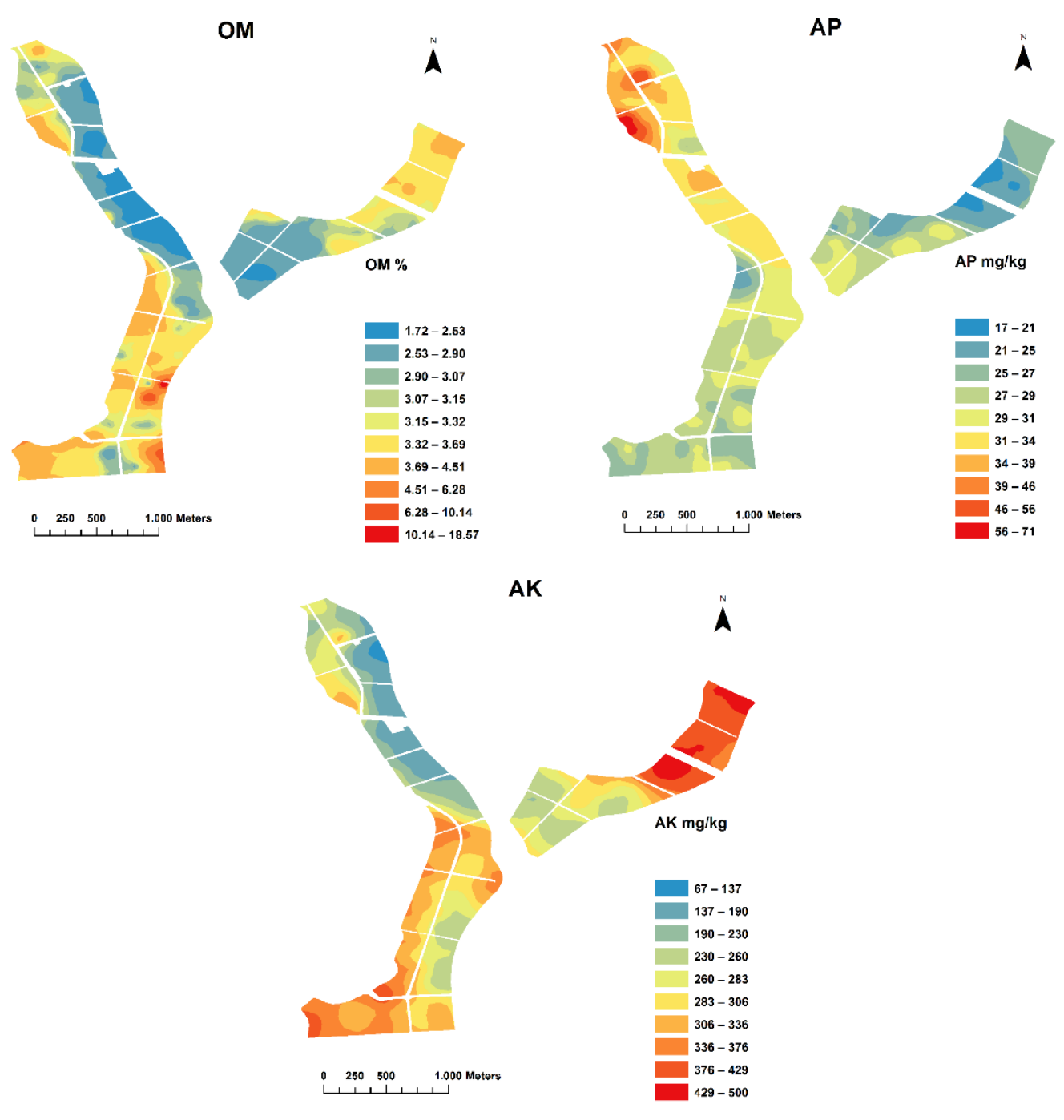

Fig. 3. Spatial distribution maps according to the most accurate techniques: soil pH (CoK_DFC) and AK (CoK_OM) with original data; EC (CoK_DFC), OM (CoK_pH) and AP (CoK_DFS) with BoxCox transformed data.

(note: print in colour) 


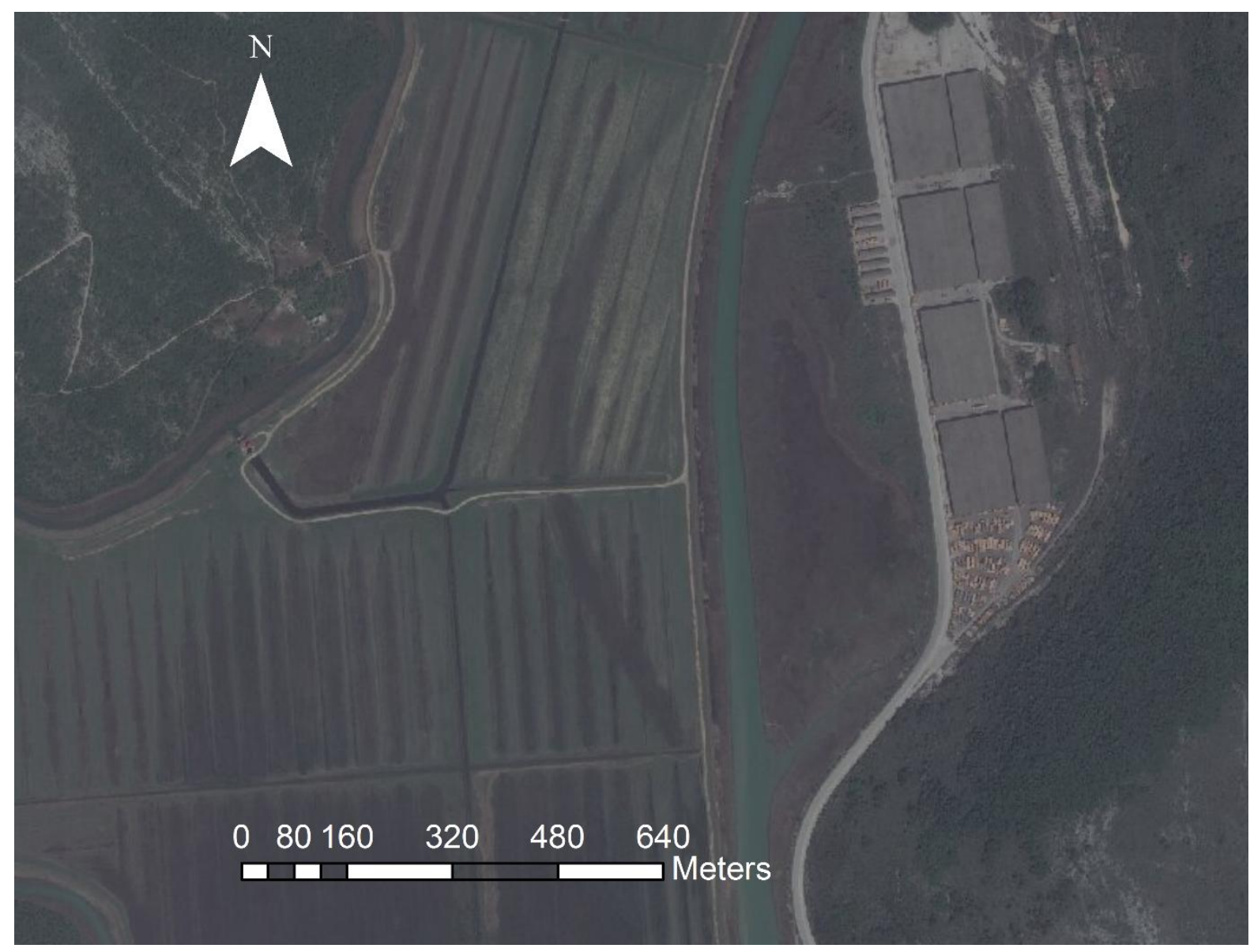

Fig. 4. Evidence of the former position of the river, seen as the green area in a form of a crescent that runs through the centre part of the photograph.

(note: print in colour) 
Tables

Table 1. The main characteristics of soils in the study area (source: Vidaček, 1977).

\begin{tabular}{|c|c|c|c|c|c|c|c|}
\hline & \multicolumn{4}{|c|}{ Anthrosols } & \multicolumn{3}{|c|}{ Colluvium soils - Gleysoils } \\
\hline & $0-35$ & & $35-90$ & $\begin{array}{l}90 \\
160 \\
\end{array}$ & $0-30$ & $30-60$ & $60-100$ \\
\hline $\mathrm{pH}\left(\mathrm{H}_{2} \mathrm{O}\right)$ & 7.7 & & 8.2 & 8.0 & 7.9 & 7.9 & 8.0 \\
\hline $\mathrm{pH}(\mathrm{KCl})$ & 7.2 & & 7.4 & 7.4 & 7.2 & 7.3 & 7.4 \\
\hline $\mathrm{CaCO}_{3}(\%)$ & 32.9 & & 30.4 & 26.5 & 32.1 & 34.14 & 35.5 \\
\hline $\begin{array}{l}\text { Organic matter } \\
(\%)\end{array}$ & 1.9 & & - & - & 1.23 & - & - \\
\hline Total N (\%) & 0.14 & & - & - & 0.12 & - & - \\
\hline $\mathrm{C} / \mathrm{N}$ & 7.8 & & - & - & 6.8 & - & - \\
\hline Sand (\%) & 8.74 & & 3.62 & 1.69 & 12.03 & 15.92 & 24.09 \\
\hline Silt (\%) & 56.57 & & 50.55 & 40.26 & 63.79 & 64.88 & 60.63 \\
\hline Clay (\%) & 34.69 & & 45.83 & 58.05 & 24.18 & 19.20 & 15.28 \\
\hline Texture & Silty & Clay & Silty & Clay & Silty & Silty & Silty \\
\hline
\end{tabular}


Table 2. Descriptive statistics of soil pH, organic matter (OM), plant available phosphorus (AP) and potassium (AK), and electrical conductivity (EC).

\begin{tabular}{|c|c|c|c|c|c|c|c|c|c|c|}
\hline Attributes & & Mean & Median & Minimum & Maximum & Range & $\begin{array}{c}\mathrm{CV} \\
(\%)\end{array}$ & $\begin{array}{c}\text { Kurto } \\
\text { sis }\end{array}$ & $\begin{array}{c}\text { Skewn } \\
\text { ess }\end{array}$ & K-S p \\
\hline \multirow{3}{*}{$\mathrm{pH}$} & Original data & 7.63 & 7.62 & 7.35 & 7.99 & 0.64 & 1.5 & 0.20 & 0.48 & 0.33 \\
\hline & Log-transformed data & 0.882 & 0.882 & 0.866 & 0.903 & 0.036 & 0.72 & 0.16 & 0.44 & 0.049 \\
\hline & Box-Cox & -0.0025 & -0.0025 & -0.0027 & -0.0022 & 0.0005 & 3.6 & 0.07 & 0.33 & 0.119 \\
\hline \multirow{3}{*}{$\mathrm{EC}(\mathrm{dS} / \mathrm{m})$} & Original data & 5.86 & 2.19 & 1.03 & 36.98 & 35.95 & 114.4 & 3.12 & 1.77 & $<0.01$ \\
\hline & Log-transformed data & 0.52 & 0.34 & 0.02 & 1.57 & 1.55 & 85.9 & -1.16 & 0.57 & $<0.01$ \\
\hline & Box-Cox & -0.45 & -0.46 & -0.97 & -0.03 & 0.94 & 70.3 & -1.65 & -0.04 & $<0.01$ \\
\hline \multirow{3}{*}{ OM (\%) } & Original data & 3.38 & 3.12 & 1.72 & 18.57 & 16.85 & 51.9 & 58.98 & 7.19 & $<0.01$ \\
\hline & Log-transformed data & 0.53 & 0.53 & 0.24 & 1.27 & 1.03 & 44.0 & 17.95 & 3.15 & $<0.01$ \\
\hline & Box-Cox & -0.55 & -0.55 & -1.00 & -0.09 & 0.91 & 21.3 & 2.76 & 0.33 & 0.015 \\
\hline \multirow{3}{*}{$\begin{array}{l}\text { AP } \\
(\mathrm{mg} / \mathrm{kg})\end{array}$} & Original data & 30.3 & 29.0 & 17.0 & 71.0 & 54 & 21.6 & 15.18 & 3.10 & $<0.01$ \\
\hline & Log-transformed data & 1.47 & 1.46 & 1.23 & 1.85 & 0.62 & 5.36 & 5.78 & 1.37 & $<0.01$ \\
\hline & Box-Cox & -0.034 & -0.036 & -0.0588 & -0.0141 & 0.045 & 16.8 & 3.04 & -0.05 & $<0.01$ \\
\hline \multirow{3}{*}{$\begin{array}{l}\mathrm{AK} \\
(\mathrm{mg} / \mathrm{kg})\end{array}$} & Original data & 287.7 & 277.0 & 67.5 & 500.0 & 432.5 & 32.8 & -0.24 & 0.32 & 0.087 \\
\hline & Log-transformed data & 2.43 & 2.44 & 1.83 & 2.70 & 0.87 & 6.4 & 0.99 & -0.72 & $<0.01$ \\
\hline & Box-Cox & 33.45 & 33.29 & 16.37 & 44.72 & 28.35 & 16.94 & -0.08 & -0.14 & 0.15 \\
\hline
\end{tabular}


Table 3. Correlations among the studied soil properties

\begin{tabular}{llllllll}
\hline & $\mathrm{pH}$ & $\mathrm{EC}$ & $\mathrm{OM}$ & $\mathrm{AP}$ & $\mathrm{AK}$ & $\mathrm{DFS}$ & $\mathrm{DFC}$ \\
\hline $\mathrm{pH}$ & - & & & & & & \\
$\mathrm{EC}$ & $0.631^{* * *}$ & - & & & & & \\
$\mathrm{OM}$ & $0.197^{* *}$ & $0.458^{* * *}$ & - & & & & \\
$\mathrm{AP}$ & $-0.461^{* * *}$ & $-0.562^{* * *}$ & $-0.207^{* *}$ & - & & & \\
$\mathrm{AK}$ & $0.311^{* * *}$ & $0.507^{* * *}$ & $0.448^{* * *}$ & $-0.395^{* * *}$ & - & & \\
$\mathrm{DFS}$ & $-0.409^{* * *}$ & $-0.517^{* * *}$ & $-0.311^{* * *}$ & $0.254^{* * *}$ & $-0.171^{*}$ & - & \\
$\mathrm{DFC}$ & $0.099^{\text {n.s. }}$ & $0.097^{\text {n.s. }}$ & $-0.089^{\text {n.s. }}$ & $-0.084^{\text {n.s. }}$ & $-0.049^{\text {n.s. }}$ & $0.024^{\text {n.s. }}$ & - \\
\hline
\end{tabular}

n.s., not significant at a $\mathrm{p}>0.05$

Significant at a ${ }^{*} \mathrm{p}<0.05,{ }^{* *} \mathrm{p}<0.01,{ }^{* * *} \mathrm{p}<0.001$

Note: EC, OM and AP were Box-Cox transformed with used lambda -1. 
Table 4. Semivariance models and their parameters for each soil property

\begin{tabular}{|c|c|c|c|c|c|c|c|}
\hline $\begin{array}{l}\text { Attribute } \\
\mathrm{s}\end{array}$ & $\begin{array}{l}\text { Data } \\
\text { transformation }\end{array}$ & $\begin{array}{l}\text { Direction } \\
\left({ }^{0}\right)\end{array}$ & Model & Nugget & Sill & $\begin{array}{l}\text { Nugge } \\
\mathrm{t} \\
\text { /Sill }\end{array}$ & $\begin{array}{l}\text { Rang } \\
\text { e } \\
(\mathrm{m})\end{array}$ \\
\hline $\mathrm{pH}$ & None & 154 & Spherical & 0.0018 & 0.0082 & 21.9 & 595 \\
\hline EC & Box-Cox & 157 & Gaussian & 0.0136 & 0.1310 & 10.4 & 1200 \\
\hline $\mathrm{OM}$ & Box-Cox & 60 & $\begin{array}{l}\text { Exponenti } \\
\text { al }\end{array}$ & 0.0013 & 0.0045 & 29.14 & 994 \\
\hline $\mathrm{AK}$ & None & None & $\begin{array}{l}\text { Exponenti } \\
\text { al }\end{array}$ & 0.00 & 7365.8 & 0.00 & 1377 \\
\hline AP & Box-Cox & 175 & $\begin{array}{l}\text { Exponenti } \\
\text { al }\end{array}$ & $\begin{array}{c}0.00000 \\
7\end{array}$ & $\begin{array}{c}0.0000 \\
2\end{array}$ & 37.3 & 545 \\
\hline
\end{tabular}


Table 5. Summary statistics of the accuracy of the tested geostatistical techniques. The most accurate method is shown in bold.

\begin{tabular}{|c|c|c|c|c|c|c|c|c|}
\hline & Min & Max & $\mathrm{ME}$ & RMSE & MSE & RMSSE & ASE & RI \\
\hline & & \multicolumn{7}{|c|}{$\mathrm{pH}$} \\
\hline $\mathrm{OK}$ & -0.2582 & 0.1851 & 0.0005 & 0.0679 & 0.0049 & 1.0513 & 0.0638 & - \\
\hline CoK_DFS & -0.2569 & 0.1910 & -0.0012 & 0.0683 & -0.2342 & 12.8590 & 0.0052 & -0.64 \\
\hline CoK_EC & -0.2508 & 0.1834 & 0.0002 & 0.0672 & 0.0011 & 1.0678 & 0.0623 & 1.01 \\
\hline CoK_OM & -0.2494 & 0.1795 & 0.0002 & 0.0679 & 0.0014 & 1.0713 & 0.0627 & -0.08 \\
\hline CoK_AP & -0.2574 & 0.1966 & 0.0001 & 0.0679 & -0.0006 & 1.0579 & 0.0635 & 0.04 \\
\hline \multirow[t]{2}{*}{ CoK_AK } & -0.2497 & 0.1799 & 0.0002 & 0.0675 & 0.0007 & 1.0529 & 0.0635 & 0.55 \\
\hline & & \multicolumn{7}{|c|}{ EC } \\
\hline $\mathrm{OK}$ & -14.0039 & 29.0192 & 2.1965 & 5.7154 & 0.1521 & 0.7394 & 11.5812 & - \\
\hline CoK_DFS & -21.8025 & 24.5215 & -0.3847 & 4.6745 & -1.4962 & 6.7061 & 2.7280 & 18.21 \\
\hline CoK_pH & -13.5224 & 26.2108 & 1.9891 & 5.3357 & 0.1871 & 0.7669 & 11.1834 & 6.64 \\
\hline CoK_OM & -14.0338 & 26.7201 & 2.0741 & 5.4769 & 0.1868 & 0.7358 & 11.3259 & 4.17 \\
\hline CoK_AP & -15.0578 & 25.3498 & 2.0978 & 5.4735 & 0.2045 & 0.7108 & 11.4938 & 4.23 \\
\hline \multirow[t]{2}{*}{ CoK_AK } & -19.5632 & 26.1561 & 1.5942 & 5.4756 & 0.0228 & 1.1735 & 9.6351 & 4.20 \\
\hline & & \multicolumn{7}{|c|}{$\mathrm{OM}$} \\
\hline $\mathrm{OK}$ & -14.8583 & 2.1185 & -0.1185 & 1.6544 & -0.1582 & 2.2486 & 0.6372 & \\
\hline CoK_DFS & -14.8595 & 2.2695 & -0.1525 & 1.6519 & -2.1194 & 20.6318 & 0.0717 & 0.15 \\
\hline CoK_pH & -12.4148 & 3.4485 & -0.1089 & 1.5052 & -0.5847 & 2.8398 & 0.3625 & 9.02 \\
\hline CoK_EC & -14.9448 & 1.4050 & -0.1048 & 1.6747 & -0.1016 & 1.8950 & 0.7666 & -1.23 \\
\hline CoK_AP & -14.8233 & 2.0517 & -0.1165 & 1.6623 & -0.1542 & 2.2759 & 0.6454 & -0.48 \\
\hline \multirow[t]{2}{*}{ CoK_AK } & -15.1293 & 2.1095 & -0.1230 & 1.6883 & -0.2470 & 2.9056 & 0.6016 & -2.05 \\
\hline & & \multicolumn{7}{|c|}{ AP } \\
\hline $\mathrm{OK}$ & -36.3657 & 7.7486 & -0.1428 & 4.3873 & -0.0460 & 1.3119 & 2.9922 & - \\
\hline CoK_DFS & -36.3114 & 9.1890 & -0.1855 & 4.3711 & -0.1125 & 1.7872 & 2.2558 & 0.37 \\
\hline CoK_pH & -36.9588 & 8.4392 & -0.1538 & 4.4241 & -0.0504 & 1.3325 & 3.0184 & -0.84 \\
\hline CoK_EC & -37.0165 & 9.6026 & -0.1974 & 4.4098 & -0.1419 & 2.0131 & 2.0639 & -0.51 \\
\hline CoK_OM & -36.7330 & 7.4861 & -0.1736 & 4.4474 & -0.0649 & 1.4371 & 2.7843 & -1.37 \\
\hline \multirow[t]{2}{*}{ CoK_AK } & -37.1187 & 8.6319 & -0.1687 & 4.5974 & -0.0319 & 1.2094 & 3.2891 & -4.79 \\
\hline & & \multicolumn{7}{|c|}{ AK } \\
\hline $\mathrm{OK}$ & -282.0449 & 155.9590 & -0.7263 & 66.8391 & -0.0076 & 1.0398 & 63.9292 & - \\
\hline CoK_DFS & -256.8240 & 169.0171 & -1.1017 & 68.9637 & -0.0137 & 1.7236 & 39.6814 & -3.18 \\
\hline CoK_pH & -282.1146 & 134.9201 & -0.7350 & 66.8610 & -0.0082 & 1.0437 & 63.8485 & -0.03 \\
\hline CoK_EC & -278.3504 & 159.3194 & -0.6448 & 67.2143 & -0.0075 & 1.0385 & 64.4247 & -0.56 \\
\hline CoK_OM & -273.4994 & 151.7916 & -0.6504 & 65.2050 & -0.0076 & 1.0264 & 63.2183 & 2.44 \\
\hline CoK_AP & -304.4576 & 149.9499 & -0.7239 & 67.7850 & -0.0086 & 1.0259 & 65.8698 & -1.42 \\
\hline
\end{tabular}

Note: Min - minimum; Max - maximum; ME - mean error; RMSE - root mean square error; MSE

- mean square error; RMSSE - root mean square standardised error; ASE - average standard error; RI - relative improvement 


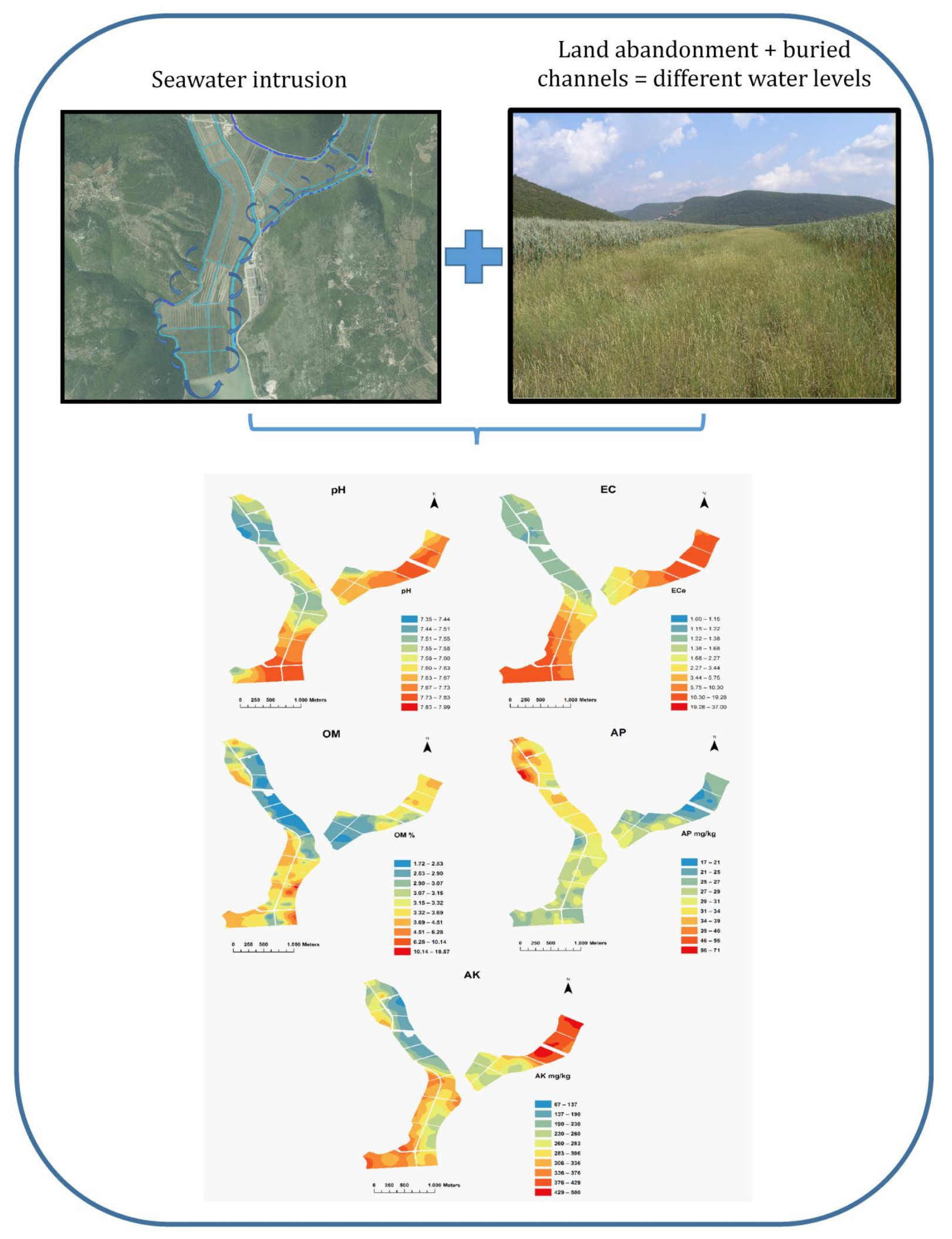

